\title{
Cruise visitors in Agios Nikolaos, Greece. Characteristics, preferences, satisfaction, and overall experience
}

DOI 10.1515/ejthr-2016-0011

received October 20, 2015; accepted February 15, 2016

\begin{abstract}
The cruise industry is exhibiting a steady significant growth during the recent years worldwide, and it is assessed to have remarkable economic implications for the local economies. The quality of cruise visitors' experiences at a destination is crucial for the inclusion of that destination on the cruise itineraries. The aim of this paper is to investigate the cruise ship visitors' off-board experiences in a Mediterranean port of call - Agios Nikolaos on the island of Crete, Greece, providing a better understanding of the main features of cruise customers' behaviour and expectations from a port of call. Primary research was conducted at the port of Agios Nikolaos during the 2014 cruise season. The 306 filled questionnaires provided useful information related to the visitors' demographic characteristics, travel motivation, destination perception, satisfaction, and intention to revisit and recommend the town to others. The findings and discussion of this study are useful to the tourism authorities of Agios Nikolaos and other Mediterranean ports of call with similar characteristics, which wish to maximise the benefits of cruise tourism, to industry practitioners, and academic researchers interested in cruise tourism.
\end{abstract}

Keywords: Cruise tourism, Cruise passengers, Experiences, Mediterranean, Port of call.

\footnotetext{
*Corresponding author: Evangelia Simantiraki, Advanced School of Tourism Education of Crete, Latous 25, 72100 Aghios Nikolaos, Crete, Tel.: +306944639853, Email: simantiraki@astecrete.edu.gr Nikolaos Trihas, Department of Business Administration, Technological Educational Institute of Crete Lakonia, 72100 Agios Nikolaos, Crete, Greece, Tel: +306944879064, E-mail: ntrihas@staff.teicrete.gr Maria Skivalou, Advanced School of Tourism Education of Crete, Latous 25, 72100 Agios Nikolaos, Crete, Greece
}

\section{Introduction}

The cruise industry has been exhibiting a significant increase of demand at an international level over the last 30 years, turning the sector into the fastest growing sector of the travel industry, with an estimated annual growth rate of $7.5 \%$ since 1980 . This is almost twice the rate of growth of tourism overall. In fact, if cruises are viewed as destinations, cruising is among the top 10 destinations, both in number and receipts (Brida \& Zapata-Aguirre, 2010). This growth, as reflected in the number of passengers worldwide, was from half a million passengers in 1970 to an estimated 22.04 million global cruise passengers in 2014 (CLIA, 2015). The dynamic sector, driven initially by demand from North America, is continuously expanding its offer of products and services and developing new markets (Dowling, 2006). As a matter of fact, although the North American cruise industry is traditionally dominant, the region's relative share of the total market has declined from 70\% in 2004 to 55\% in 2013 (Ward, 2013). On the other hand, the European market has grown by $14 \%$ over the past 3 years and by 146\% over the last 10, accounted in 2014, for 30\% of all itineraries (CLIA, 2015; Florida Caribbean Cruise Association, 2014). In fact, Europe is considered as a key market for the global cruise industry. With 6.39 million Europeans cruising in 2014, Europe represents the second biggest source market worldwide, after the USA. Europe is also the number two cruise destination in the world, after the Caribbean, having received 5.85 million cruise passengers last year. All of this translates into an economic value for Europe. The cruise industry's total economic output reached $€ 40.2$ billion in 2014 , up by $2 \%$ from the previous year, including $€ 16.6$ billion in direct spending by cruise lines, their passengers, and crew (CLIA, 2015). Because of this rapid expansion, the cruise sector has been a subject of considerable research interest over the last two decades.

The aim of this paper is to investigate the characteristics of the cruise ship visitors to a small Mediterranean port of call, that is, Agios Nikolaos, Crete, Greece, in order 
to provide a better understanding of the various aspects of their visit, such as their motivation, activities, experiences, and spending in the town, along with satisfaction with the destination and intentions for revisiting or recommending it as a travel destination to others. This study is the first empirical study realised in the port of Agios Nikolaos, and the motivation to conduct it was the growing importance of the cruise tourism for the local economy and the intense competition with other cruise ports of call. Its outcomes are expected to be particularly useful to destination managers and the local government and to contribute to the planning of the area's tourist development and promotion strategies.

The paper is divided into six parts. Following this introduction, section 2 presents a brief literature review on the research related to the cruise passengers' experiences in ports of call. Section 3 briefly presents the town of Agios Nikolaos as a cruise tourism destination. Section 4 introduces the methodology of the research, while section 5 elaborates on the results, presenting both the demographic characteristics of the respondents as well as several aspects of their experience in the town, such as their motivation, satisfaction, and intention to revisit and recommend the destination to others. Finally, in section 6, the implications of the study and its findings along with the limitations encountered are discussed.

\section{Literature review}

Cruising has experienced an increasing popularisation and remarkable growth during the recent years. Today, cruising is assessed to have significant economic implications for the local economies worldwide. Due to these economic benefits and the continuous increase in the number of cruise ports of call, the ports are struggling to gain a competitive advantage over other ports and encourage cruise companies to visit those (Busby \& O'Neill, 2013). Following its significance as an economic factor, research on cruise tourism has lately become popular, although most of it has been focussed on Caribbean destinations (Brida, Pulina, Riaño, \& Zapata-Aguirre, 2012b, 2013; Chase \& Alon, 2002; Mackay Yarnal \& Kerstetter, 2005; Petrick, 2004b, 2005; Weaver, 2005). The number of available studies on popular ports of call other than the Caribbean is limited, while a number of studies have dealt with analysing the cruise passengers' off-board experiences in a port of call. As a matter of fact, several studies refer to the experience of cruisers within the ship, but only a few on the cruisers' experience in the port of call.
Moreover, there is a scarcity of empirical studies on the cruise passengers' expenditure behaviour in a port of call (Brida et al., 2013).

The intentions to revisit and to recommend a port of call to others have been an important area of research in the cruise tourism industry. Brida et al. (2012a) analysed the cruise visitors' intention to return as land tourists to Cantagena de Indias (Colombia) and the probability to recommend the visited destination by adapting a structural equation model. Gabe, Lynch, and McConnon (2006) investigated the factors influencing the cruise visitors' intention to return to the port of Bar Harbor, USA. Silvestre, Santos, and Ramalho (2008) conducted a research with similar objectives for Azores. Miriela and Lennie (2010) applied a logit model to examine the factors that appear to motivate the cruise visitors to Curaçao to return as land-based tourists to the island. Hosany and Witham (2010) collected data from tourists disembarking from a two-week cruise in Asia, in order to identify the underlying dimensions of the cruisers' experiences and investigate the relationship between the cruisers' experiences, satisfaction, and intention to recommend. Kim and Brown (2012) conducted a research in South Australia to examine the impacts of perceived travel experiences and personal characteristics on the overall satisfaction and destination loyalty. The relationship between satisfaction, perceived value, and quality in the prediction of intentions to repurchase and positive word-of-mouth publicity was investigated by Hui, Wan, and Ho (2007) and Petrick (2004a, 2005). They all found that higher satisfaction is influential in generating positive word-of-mouth.

There is limited of research on the cruise passengers visiting Mediterranean destinations although the Mediterranean includes very important cruise destinations, such as Barcelona, Civitavecchia, Venice, Palma Majorca, Piraeus, and many others (CLIA, 2015). Andriotis and Agiomirgianakis (2010) investigated various aspects of cruise ship clientele visiting Heraklion, Crete. Blas and Carvajal-Trujillo (2014) collected data from the port of Valencia and analysed the relationship between the destination image and satisfaction, that is, the influence of the cruise passengers' image of a port of call on visit satisfaction and future behavioural intentions. Di Vaio and Penco (2013) addressed the effect of overall destination satisfaction on the cruiser's 'word-of-mouth behaviour' with a survey to a sample of cruise passenger in the port of Messina, Italy. Likewise, Pranic, Marusic, and Sever (2013) investigated the influence of satisfaction factors and demographics of micro-cruise travellers in Croatia on revisit and word-of-mouth intentions. 


\section{Port of call: Agios Nikolaos, Crete}

Agios Nikolaos, capital of the Lasithi Prefecture, is a small coastal town of 9,500 residents, situated in the Eastern part of Crete. Its tourism development, based on the $3 \mathrm{~S}$ model, started in the early 1960s, and today, it is a well-established international and cosmopolitan summer resort, welcoming thousands of visitors every year. Yet, it has begun to suffer from the disadvantages of mass tourism, that is, the strong competition from other popular destinations, the seasonality in arrivals, the shrinkage of the tourism season, the dependence on international tour operators, and the all-inclusive system (Skivalou \& Trihas, 2012). As a reaction, local authorities direct their efforts to differentiate the tourist product and promote special interest and alternative forms of tourism in the region, as is the cruise tourism.

The cruise tourism in Agios Nikolaos can be traced back in 1987, when small Russian cruise ships used to arrive every Saturday, carrying passengers from Israel. These weekend visitors were entertained in the local shops and enjoyed themselves at Cretan nights organised in the town. Then, after a break that lasted for about 10 years, in year 2000, several medium-sized cruise ships at the beginning, and larger vessels recently, started to arrive again on a regular basis to the port. As a matter of fact, during the last 15 years, the interest of cruise lines has increased, the cruise industry is evolving rapidly, and higher capacity cruise ships are including the port in their itineraries. Specifically, according to the data obtained from the local port authority, the annual cruise ship arrivals increased by $230 \%$, from 20 arrivals in 2000 to 66 arrivals in 2014 (with a peak of 102 arrivals in 2011). During the same period, the average number of passengers per cruise ship more than doubled (for annual data, see also Simantiraki \& Skivalou, 2013).

The passenger port is located in the heart of the town and two modern docks of $136 \mathrm{~m}$ and $209 \mathrm{~m}$ length each are capable of accommodating two medium-sized ships (250 $m$ length max if they berth alongside the pier). The port basin of $10 \mathrm{~m}$ depth provides sufficient space and depth for cruise ship manoeuvring. Unfortunately, a passenger terminal port is still missing from the port, although its construction has been among the priorities of the local authority during the recent years (Simantiraki \& Skivalou, 2013). Among the facilities provided to the cruise visitors in the port are an information kiosk and WC facility.

Agios Nikolaos is a town of natural beauty. The port is located just a few minutes' walk from the town's shops, cafés, and restaurants, and it does not host any other regular commercial or passenger activity, and thus, it offers the visitors a secure and hospitable environment. Besides, the town serves as a hub to the 20 or so small villages and farms that make up that part of Lasithi, and it provides an easy access to several places of cultural heritage value, as is the historic island of Spinalonga or the Minoan Palace of Knossos in the adjacent Heraklion Prefecture. Consequently, the area offers the tourists many attractions and interesting experiential activities to be involved in during their stay.

\section{Methodology}

To the authors' best knowledge, this is the first research conducted on the cruise ship visitors to the town of Agios Nikolaos, aiming to investigate the aspects of their offboard experience. The tool of this research was a self-completed questionnaire consisting of 21 questions. In designing the questionnaire, the authors took into account the various concerns of the local authorities, tourism policy makers, and shipping agents, that arose in the interviews realised for this purpose by Simantiraki and Skivalou (2013), as well as similar older research realised for the town of Heraklion, Crete, by Dimou and Simantiraki (2010). The questionnaire was administered only in English, as this was considered sufficient according to the information on the profile of the cruise visitors in Agios Nikolaos provided by the local shipping agents, and it was comprised of four sections. The first section assembles the general information on the visitors' geographic origin, the number of persons in travelling party, the main reason for choosing cruise vacation, the number of cruises taken in the last 5 years, and if this was their first visit to the town. The second section contained questions regarding several aspects of their visit; the time spent off the cruise ship, the activities undertaken, as well as their expenditure behaviour. In the third section, the visitors were asked to indicate their satisfaction and level of agreement to a number of statements regarding their visit to the town using the five-point Likert scales. The objective of this section was to investigate the degree of satisfaction acquired from the experience they had in the town, as this has been found in the literature to influence the likelihood of a return visit (Gabe et al., 2006). Their intentions to visit Agios Nikolaos again in the future or recommend it to relatives and friends were investigated, along with their willingness to purchase a package combining the cruise with a few days accommodation in a luxury resort in the area, if they were given the choice by the cruise operator. The last section contained questions about the respondents' 
profile, utilising several demographic variables, that is, age, gender, education, income, employment, and so on. The survey took place in the port of Agios Nikolaos between July, 1st and October, 31st, 2014. There were approximately 19,476 passengers disembarked in the port during this period of time - an estimated $85 \%$ of the ones that arrived, according to the data obtained from the port authority. The cruise ship passengers, older than 18 years were approached at random, as they were returning to the cruise ship, they were informed of the nature of the survey and asked to complete the questionnaire. 900 questionnaires were distributed and 304 filled questionnaires were collected (33.8\% response rate).

The collected data were statistically analysed using the Statistical Package for the Social Sciences (SPSS) version 22.0. Descriptive statistics were used to investigate the passengers' perceptions of the destination Agios Nikolaos. To investigate the relationship between the 'passengers' attitudes, a series of one-way analysis of variance (ANOVA) were conducted.

\section{Results}

\subsection{The respondent's profile}

A total of 304 questionnaires were collected, and Table 1 presents the demographic and other characteristics of the respondents. The female respondents were slightly dominant $(55.6 \%)$, and $86.2 \%$ of the respondents were married or living common law at the time of the research. In terms of ages, only $4.7 \%$ of the respondents were under 45 years of age, $43.5 \%$ were between 45 and 64 , and $51 \%$ were above 65. Accordingly, retired people comprised the largest proportion of the sample (62.8\%). 32.3\% of the respondents were employed (full-time, part-time, or seasonally) at the time of the research. More than half of the respondents (72.3\%) had graduated college, and moreover, $17.4 \%$ had earned a postgraduate degree. Interestingly, the respondents were reluctant to reveal their family income, and $45 \%$ refused to answer the relevant question. Among the ones that replied, $21.6 \%$ declared that their last year' $\mathrm{s}$ total annual household income (before taxes and deductions) was less than 25,000 Euros, $44.3 \%$ had a income between 25,000 and 54,999 Euros, $14.4 \%$ between 55,000 and 74,999 Euros, and, 19.8\% more than 75,000 Euros, thus nowadays, consumers of different economic status seem to choose cruise vacationing. In terms of the country of origin (usual place of residence), the vast majority of the respondents (91.4\%) originated from the UK, and only $8.6 \%$ from other countries, and specifically Australia, New Zealand, Cyprus, USA, and Egypt, in descending order of the percentages. Actually, among the European countries, the main source market for cruising in 2014 has been Germany, with 1.77 million passengers, followed by the UK and Italy, with $1,644,000$ and 842,000 passengers, respectively (CLIA, 2015). However, the dominant nationality globally, of customers preferring the cruise tourism, is the US nationality, and as a result, there is a scarcity of empirical data from European clientele in the literature (Andriotis \& Agiomirgianakis, 2010; Diakomihalis, Lekakou, Stefanidaki, \& Syriopoulos 2009). Thus, the findings of this research could be useful for the cruise tourism researchers.

Subsequently, the respondents were asked to state the number of people, including themselves, in their travelling party, that is, the number of people travelling with them for whom they could report spending and travel activities. It turned out that the majority (85.9\%) travelled with their partner, $10.5 \%$ travelled with their family or in parties of three and more, and only $3.6 \%$ travelled alone. Moreover, this research revealed for one more time that cruisers are repeaters, since, for the majority of the respondents, $76.3 \%$, this was not their first cruise ever. As a matter of fact, $13 \%$ of them had taken 1-2 cruises during the last 5 years, 22\% had 3-4 cruises, and a considerable $24 \%$ stated that they take at least 1 and up to 3 cruises every year. When the respondents were asked why they chose cruise vacation this particular time, 34.9\% characterised themselves as 'cruise repeaters', anyway, whereas a considerable proportion (38.9\%), stated that it offered them 'better value for money', indicating that these days, cruises are not considered as a 'luxury product', but are gradually becoming attractive to consumers of different economic status (see also CLIA, 2015; Diakomihalis et al., 2009). Moreover, almost $7 \%$ of the respondents reported that they were inspired by the specific itinerary, and 2.8\% reported that they chose the cruise to celebrate a special occasion.

\section{The respondents' experience in the town of Agios Nikolaos}

\subsection{Types of activities undertaken}

For the majority of the respondents (83.2\%), this was their first trip to the town of Agios Nikolaos, whereas about 
Table 1: Respondents' Profile - socio-demographic information

\begin{tabular}{|c|c|c|}
\hline Demographics & & Percentage \\
\hline \multirow[t]{2}{*}{ Gender } & Male & 44.4 \\
\hline & Female & 55.6 \\
\hline \multirow[t]{2}{*}{ Marital status } & Married & 86.2 \\
\hline & Not married & 11.8 \\
\hline \multirow[t]{4}{*}{ Age } & 18 to 44 & 4.7 \\
\hline & 45 to 44 & 43.5 \\
\hline & 65 to 74 & 41.8 \\
\hline & 75 and over & 9.2 \\
\hline \multirow[t]{5}{*}{ Education } & Less than high school & 5.6 \\
\hline & High school diploma & 13.5 \\
\hline & Some post-secondary & 11.2 \\
\hline & $\begin{array}{l}\text { Graduated community/technical } \\
\text { college or university }\end{array}$ & 37.5 \\
\hline & Post-graduate degree & 17.4 \\
\hline \multirow{7}{*}{$\begin{array}{l}\text { Employment } \\
\text { status }\end{array}$} & Working full-time & 23.7 \\
\hline & Working part-time or seasonally & 8.6 \\
\hline & Unemployed & 0.7 \\
\hline & Retraining or upgrading & 0.3 \\
\hline & Retired & 62.8 \\
\hline & Homemaker & 1.3 \\
\hline & Student & 0.3 \\
\hline \multirow[t]{4}{*}{ Total income } & Under $€ 25,000$ & 21.6 \\
\hline & $€ 25,000$ to $€ 54,999$ & 44.3 \\
\hline & $€ 55,000$ to $€ 74,999$ & 14.4 \\
\hline & $€ 75,000$ or more & 19.8 \\
\hline \multirow{6}{*}{$\begin{array}{l}\text { Country of } \\
\text { residence }\end{array}$} & UK & 91.4 \\
\hline & Cyprus & 1.3 \\
\hline & Australia & 4.9 \\
\hline & New Zealand & 1.6 \\
\hline & USA & 0.3 \\
\hline & Egypt & 0.3 \\
\hline
\end{tabular}

$9.2 \%$ of them had been in the town once during the last 5 years, 4.6\% twice, and 1.6\% 3-4 times. Moreover, among the respondents who had visited the town in the past, $49.1 \%$ realised that the visit within the past 3 years, and $43.1 \% 4$ or more years before the year of the research $(7.8 \%$ did not answer the relevant question).
The average time spent by the participants of the research, off the cruise ship was $5 \mathrm{~h}$ and $48 \mathrm{~min} .38 .5 \%$ of them spent 6 and more hours off-board and 13.8\%, 8 hours or more. During this short visit, cruisers were able to visit the attractions of the town, entertain themselves at the lakeside cafes, discover traditional Cretan cuisine and quality wines at the restaurants, and purchase their souvenirs. However, $69.7 \%$ of the respondents joined a guided excusion that took them away from the town as soon as they disembarked, and thus, spent much less time in the town when they returned. The most popular excursions were, in descending order of preference, the visit to Spinalonga, an excursion called 'Panoramic Crete', and the visit to the Palace of Knossos. On the other hand, unfortunately, almost half (48.9\%) of the respondents who stayed behind, did not reveal in what activities they were involved, while $22.8 \%$ of them joined a guided train or walking tour of the town, and the remaining $28.3 \%$ spent their time walking, shopping, dining, and visiting the town's historic attractions on their own.

The total spending in the town by all the members of the respondent's travelling party, excluding the amount prepaid to the tour operator for the purchase of the cruise package, was also investigated. Taking into account the number of persons included in spending, the average spending per visitor was 31.57 Euros, which is well below the average of 62 Euros spent by the cruise passengers at European ports of visits in 2014 (CLIA, 2015). Although the number of respondents from countries other than the UK was small to trust, research revealed that visitors from Australia and the USA spent well above the average, 72.60 and 50.00 Euros per person, respectively. Regarding the expenditure patterns, according to the respondents' estimates, $57.5 \%$ of the spending was on purchasing organised bus tours and excursions, $17.3 \%$ on the consumption of food and beverages, $2.6 \%$ on car rentals and transportation, $4.5 \%$ for recreation and entertainment activities, and $18.1 \%$ on all other goods and services, that is, shopping for souvenirs, and so on.

\subsection{Trip evaluation}

In the following question, the participants were asked to indicate in a scale of 1 to 5 how they would rate their trip to Agios Nikolaos with regard to six different aspects. Overall, the participants rated high all those aspects. Specifically, $92.1 \%$ of the visitors found the 'welcome' provided to them by the municipality as 'good' or 'excellent', $90.1 \%$ felt the same for the restaurants' service and quality, $95.6 \%$ for the transportation service and quality, and $93.7 \%$ for the 
overall quality of customer service. Table 2 provides also the mean evaluation of the six different aspects. It turned out that the lowest satisfaction was expressed for the 'prices of goods and services', followed by, the 'variety of things to see and do in the town'.

Subsequently, the participants were asked to indicate in a scale of 1 (Strongly Disagree) to 5 (Strongly Agree) their perceptions, judgments, or feelings regarding five statements concerning the town of Agios Nikolaos as a port of call. $48.6 \%$ of the respondents felt neutral about the inclusion of Agios Nikolaos in the itinerary. As a matter of fact, some of the participants mentioned that Agios Nikolaos was not in the original itinerary, but it was a substitute, mostly due to problems in Egypt at the time of the cruise. However, $53.7 \%$ of the respondents thought that the town was one of the best destinations visited on that cruise, whereas $41.9 \%$ felt neutral about this statement as well. $81.8 \%$ of the participants thought that the time provided for the stopover in the town was sufficient, and only 5.4\% felt that this time was not enough. This is probably an indication that the respondents felt that there was not much more to do in the town. However, $75.9 \%$ of them felt that there were suitable activities offered on the port. Last but not least, $80.2 \%$ of the respondents would recommend Agios Nikolaos as a travel destination to others.

Subsequently, the participants in the research were asked if they will revisit Agios Nikolaos at some time in the near future. $24.4 \%$ of them replied that they will certainly revisit, 47.7\% that they may revisit, and only $14.2 \%$ were unlikely to revisit. Moreover, when they were asked whether they would consider purchasing a package combining the cruise with a week in a luxury resort in the area, if such a deal was oferred by the cruise line, 53.3\% of the respondents felt possitive about this option, whereas $39.5 \%$ expressed no interest in it.
The application of ANOVA to investigate the significant effects of the demographic characteristics of the respondents (gender, age, marital status, education, employment status, income, and country of residence) on their ratings of the six aspects of the trip to Agios Nikolaos (see Table 2) revealed some statistically significant effects in a couple of cases. Namely, income appeared to have some influence ( $p=0.036)$ on the visitors' satisfaction with the 'quality of transportation service' and the country of origin on satisfaction with 'the welcome provided to cruise ship passengers' ( $p=0.001)$; however, the latter is not to be trusted because of the low representation of different geographic origins in the sample.

Moreover, some significant effects $(\mathrm{p}<0.05)$ were detected concerning the visitors' level of agreement on the various statements regarding the town (Table 3). Specifically, unmarried and higher income people tend to agree more with the statement 'there were suitable activities offered during the time in port'. Moreover, older people tend to agree more with the statement that 'the inclusion of Agios Nikolaos in the itinerary was an important reason for selecting the cruise'. The demographic characteristics do not play a significant role in the respondents' stated intention to return to the town or to recommend it as a travel destination to friends and relatives. However, satisfaction with the 'welcome provided to cruise ship passengers', the 'restaurant service and quality', and the 'quality of service provided', all demonstrated a positive influence on these intentions. Thus, data revealed, once more that the human capital of an area, as defined in terms of satisfaction with the services provided, play an important role in forming these decisions (see also Blas \& CarvajalTrujillo, 2014; Pranic et al., 2013; Brida et al., 2013).

Table 2: Visitors' evaluation for various aspects of their trip to Agios Nikolaos

\begin{tabular}{|c|c|c|c|c|c|c|c|}
\hline & \multicolumn{2}{|l|}{$\begin{array}{l}\text { Very } \\
\text { poor }\end{array}$} & \multicolumn{2}{|c|}{ Average } & \multirow{2}{*}{$\begin{array}{l}\text { Excellent } \\
5\end{array}$} & \multirow[t]{2}{*}{ Mean } & \multirow[t]{2}{*}{ Std. deviation } \\
\hline & 1 & 2 & 3 & 4 & & & \\
\hline Welcome provided to the cruise ship passengers & 0.0 & 1.0 & 6.9 & 41.2 & 50.9 & 4.42 & 0.667 \\
\hline Restaurant service and quality & 0.0 & 0.0 & 9.9 & 48.4 & 41.7 & 4.32 & 0.645 \\
\hline Transportation service and quality & 0.0 & 0.0 & 4.4 & 50.0 & 45.6 & 4.41 & 0.576 \\
\hline Quality of customer service & 0.0 & 0.4 & 5.9 & 49 & 44.7 & 4.38 & 0.615 \\
\hline Prices of goods and services & 0.4 & 1.2 & 24 & 48.3 & 26 & 3.98 & 0.767 \\
\hline Variety of things to see and do & 0.8 & 1.2 & 21.5 & 45.4 & 31.2 & 4.05 & 0.801 \\
\hline
\end{tabular}


Table 3: Visitors' level of agreement on various statements regarding Agios Nikolaos

\begin{tabular}{|c|c|c|c|c|c|c|c|}
\hline & $\begin{array}{l}\text { Strongly } \\
\text { disagree }\end{array}$ & Disagree & $\begin{array}{l}\text { Neither } \\
\text { agree or } \\
\text { disagree }\end{array}$ & Agree & $\begin{array}{l}\text { Strongly } \\
\text { agree }\end{array}$ & Mean & $\begin{array}{l}\text { Std. } \\
\text { deviation }\end{array}$ \\
\hline & 1 & 2 & 3 & 4 & 5 & & \\
\hline $\begin{array}{l}\text { The inclusion of Agios Nikolaos in the itinerary } \\
\text { was an important reason for selecting the cruise }\end{array}$ & 4.7 & 10.9 & 48.6 & 24.3 & 11.6 & 3.27 & 0.966 \\
\hline $\begin{array}{l}\text { Agios Nikolaos was one of the best destinations } \\
\text { we have visited on this cruise }\end{array}$ & 0.9 & 3.5 & 41.9 & 43.7 & 10 & 3.59 & 0.754 \\
\hline $\begin{array}{l}\text { Sufficient time was provided for the stopover in } \\
\text { Agios Nikolaos }\end{array}$ & 0.7 & 4.7 & 12.7 & 60.7 & 21.1 & 3.97 & 0.771 \\
\hline $\begin{array}{l}\text { There were suitable activities offered during the } \\
\text { time on the port }\end{array}$ & 0.0 & 2.3 & 21.9 & 60.4 & 15.5 & 3.89 & 0.674 \\
\hline $\begin{array}{l}\text { I will recommend Agios Nikolaos as a travel } \\
\text { destination to others }\end{array}$ & 0.7 & 0.4 & 18.5 & 58.1 & 22.2 & 4.01 & 0.700 \\
\hline
\end{tabular}

\section{Conclusions}

The primary research for this study was carried out among the passengers of cruises docking at Agios Nikolaos, Crete, between June and October 2014. One of the difficulties encountered during data collection was that the size of the target population was unknown at the time of the research. In order to obtain the sample of the survey, the passengers were randomly approached before their return to the cruise ship. Frequently, though, they were tired and anxious to return to the cruise ship, and thus, unwilling to participate in the survey. In a couple of cases, the authors managed to convince the cruise line to allow them to administer the questionnaire on-board the cruise ship, but then, one has to avoid the passengers who stayed on-board and never visited the town. Moreover, with the help of a local agent, some questionnaires were offered on-board the buses that were returning the passengers to the port after their excursion, but this again had the drawback that those respondents at the time of the research hadn't had the chance yet, to explore the town itself. Another limitation of this study was that although data were collected on different days, from different ships in order to ensure sample variability, $91 \%$ of the respondents were UK nationals, and hence, different geographic origins were not represented in the sample. This preponderance of the UK origin in the sample is due to: 1) the fact that UK represents one of the main sources of the cruise market in Europe, 2) UK residents traditionally show a preference to the town of Agios Nikolaos, as many of them choose it for their land-based vacations as well, and 3) their willingness compared with other nationalities to participate in the survey.

The respondents, in general, enjoyed their visit to Agios Nikolaos and expressed their willingness to revisit at some point in time and recommend the town as a travel destination to others. They found the 'place fabulous', the 'scenery amazing', the 'lakeside shops excellent', and the 'people friendly and accommodating'. Moreover, almost everyone had something good to say about their tour guide. Moreover, more than half of the town's visitors would like to combine the cruise with a luxury hotel package in the area. Among the respondents' negative remarks, were the prices at the cafés and the local shops, as well as the limited opening hours of the museums and archaeological sites.

The authors believe that Agios Nikolaos can increase its share of the market and even become one of the popular cruise destinations in Greece, especially since the majority of cruises usually visit more than one of the Greek ports (Diakomihalis et al., 2009). The cruise vacationers love to visit multiple ports and the cruise lines are willing to change the itineraries and include ports of call that provide positive in-port experiences. All it takes is for the local tourism stakeholders and policy makers to concentrate on the strategies that will increase the visitors' level of satisfaction by offering various interesting activities experiences in the area, at reasonable prices (Simantiraki \& Skivalou, 2013). 


\section{References}

[1] Andriotis, K. \& Agiomirgianakis, G. (2010). Cruise Visitors' Experience in a Mediterranean Port of Call. International Journal of Tourism Research, 12(4), pp. 390-404

[2] Blas, S.S. \& Carvajal-Trujillo, E. (2014). Cruise Passengers' Experiences in a Mediterranean Port of Call. The Case of Valencia. Ocean \& Coastal Management, 102, pp. 307-316

[3] Brida, J.G., \& Zapata-Aguirre, S. (2010). Cruise Tourism: Economic, Socio-Cultural and Environmental Impacts. International Journal of Leisure and Tourism Marketing, 1(3), pp. 205-226

[4] Brida, J.G., Pulina, M., Riaño, E. \& Zapata-Aguirre, S. (2012a). Cruise Visitors' Intention to Return as Land Tourists and Recommend a Visited Destination. Anatolia: An International Journal of Tourism and Hospitality Research, 23(3), pp. 395-412

[5] Brida, J.G., Pulina, M., Riaño, E. \& Zapata-Aguirre, S. (2012b). Cruise Passengers' Experience Embarking in a Caribbean home port. The Case Study of Cantagena de Indias. Ocean \& Coastal Management, 55, pp. 135-145

[6] Brida, J.G., Pulina, M., Riaño, E. \& Zapata-Aguirre, S. (2013). Cruise Passengers in a Homeport: A Market Analysis. Tourism Geographies, 15(1), pp. 68-87

[7] Busby, G. \& O'Neill, J. (2013). Ports of Call: In Search of Competitive Advantage. European Journal of Tourism, Hospitality and Recreation, 4(1), pp. 123-160

[8] Chase, G. \& Alon, I. (2002). Evaluating the Economic Impact of Cruise Tourism: A Case Study of Barbados. Anatolia: An International Journal of Tourism and Hospitality Research, 13(1), pp. 5-18

[9] CLIA (2015). The Cruise Industry. Contribution of Cruise Tourism to the Economies of Europe. Brussels: Cruise Lines International Association

[10] Diakomihalis, M.N., Lekakou, M.B., Stefanidaki, E. \& Syriopoulos, T.C. (2009). The Economic Impact of the Cruise Industry on Local Communities: The Case of Greece. 4th International Conference of the Aegean University, 'Planning for the Future - Learning from the Past: Contemporary Developments in Tourism, Travel \& Hospitality', Rhodes Island, Greece, April 2009

[11] Dimou, I. \& Simantiraki, E. (2010). Cruise Tourism vs. Hotel Accommodation: A Substitute or Supplementary Relationship. A Preliminary Analysis for the City of Heraklion. Proceedings of the 2nd International Conference on Tourism and Hospitality Management, pp. 58-74

[12] Di Vaio, A. \& Penco, L. (2013). Cruise Passengers Value in Seaport Destination: An empirical analysis. IAME 2013 Conference. Paper ID306. Marseille, France

[13] Dowling, R. (2006). The Cruising Industry. In R. Dowling (Ed.), Cruise Ship Tourism. Oxfordshire: CAB International

[14] Florida Caribbean Cruise Association (2014). Cruise Industry Overview. USA: Florida

[15] Hui, T.K., Wan, D. \& Ho, A. (2007). Tourists Satisfaction, Recommendation and Revisiting Singapore. Tourism Management, 28(4), pp. 965-975

[16] Hosany, S. \& Witham, M. (2010). Dimensions of Cruisers' Experiences, Satisfactions and Intention to Recommend. Journal of Travel Research, 49(3), pp. 351-364
[17] Gabe, T.M., Lynch C.P. \& McConnon J.C. (2006). Likelihood of Cruise Ship Passenger Return to a Visited Port: The Case of Bar Harbor, Maine. Journal of Travel Research, 44, pp. 281-287

[18] Kim, A.K. \& Brown, G. (2012). Understanding the relationships between perceived travel experiences, overall satisfaction, and destination loyalty. Anatolia: An International Journal of Tourism and Hospitality Research, 23(3), pp. 328-347

[19] MacKay Yarnal, C.M. \& Kerstetter, D. (2005). Casting off. An Exploration of Cruise Ship Space, Group Tour Behavior, and Social Interaction. Journal of Travel Research, 43, pp. 368-379

[20] Miriëla, C. \& Lennie, P. (2010). Cruise tourists returning to Curacao for a land based vacation: A logit model. Netherlands: Research Department of the Central Bank of the Netherlands Antilles

[21] Petrick, J.F. (2004a). The Roles of Quality, Value, and Satisfaction in Predicting Cruise Passengers' Behavioral Intentions. Journal of Travel Research, 42(4), pp. 397-407

[22] Petrick, J.F. (2004b). First Timers' and Repeaters' Perceived Value. Journal of Travel Research, 43, pp. 29-38

[23] Petrick, J.F. (2005). Segmenting Cruise Passengers with Price Sensitivity. Tourism Management, 26, pp. 753-762

[24] Pranic, L, Marusic, Z. \& Sever, I. (2013). Cruise passengers' experiences in coastal destinations - Floating "B\&Bs" vs. floating "resorts": A case of Croatia. Ocean \& Coastal Management, 84, pp. 1-12

[25] Silvestre, A., Santos, C.M. \& Ramalho, C. (2008). Satisfaction and Behavioral Intentions of Cruise Passengers visiting the Azores. Tourism Economics, 14(1), pp. 169-184

[26] Simantiraki, E. \& Skivalou, M. (2013). Cruise Ship Tourism: Development and Prospects for the Town of Agios Nikolaos (Crete, Greece). Tourism Today, 13, pp. 7-19

[27] Skivalou, M. \& Trihas, N. (2012). Developing special interest tourism in a $3 \mathrm{~S}$ destination. The case of yachting tourism and the marina of Agios Nikolaos, Crete. International Conference on Tourism (ICOT2012) 'Setting the Agenda for Special Interest Tourism: Past, Present and Future', 23-26 May, Archanes, Crete, Greece

[28] Ward, D. (2013). Complete Guide to Cruising \& Cruise Ships 2013. London: Berlitz

[29] Weaver, A. (2005). Spaces of Containment and Revenue Capture: 'Super-Sized' Cruise Ships as Mobile Tourism Enclaves. Tourism Geographies, 7(2), pp. 165-184

Evangelia Simantiraki is an assistant professor of Mathematical Economics and Statistics at the Advanced School of Tourism Education of Crete, Greece. Previously, she was an adjunct professor at the Department of Economics of the University of Crete and at the Department of Tourism and Hospitality Management of the Technological Educational Institute of Crete. Her research interests are in the areas of mathematical programming and optimisation, and more recently, in tourism research and tourism education.

Maria Skivalou is lecturer at the Advanced School of Tourism Education in Crete. She holds B.A. in Marketing from the City University of Seattle and an Msc in 
Management from Sheffield Hallam University. She is a businesswoman herself, owning a retail shop. Her publications include various articles in Tourism and Hospitality journals. She regularly attends international conferences, where she presents her various research topics.

Nikolaos Trihas holds a $\mathrm{PhD}$ in e-Tourism, a Master's Degree (MSc.) in Tourism Planning, Administration and Policy, and a BSc. in Business Administration from the University of the Aegean, Greece. Currently, he is a lecturer in the Department of Business Administration at the Technological Educational Institute of Crete and in the Hellenic Open University in Greece, where he lectures courses on marketing, management and tourism. 